\title{
Association Between Personal and Environmental Factors, Body Position on Low Back Pain at Dr. Moewardi Hospital, in Surakarta
}

\author{
Rina Kurnia'), Rita Benya Adriani'), Argyo Demartoto²) \\ ${ }^{1)}$ Health Polytechnic, Ministry of Health Surakarta \\ ${ }^{2)}$ Faculty of Social and Political Sciences, Universitas Sebelas Maret
}

\begin{abstract}
Background: Low back pain (LBP) often encountered in daily practice, especially in industrialized countries. The study showed that $90.9 \%$ of LBP patients experienced a relapse more than once in a year, the relapse was triggered by personal factor, work environment and lack of health information. The purpose of this study was to analyze factors associated with recurrence prevention in patients with low back pain at Medical Rehabilitation Instalation Dr. Moewardi, Surakarta Hospital

Subjects and Method: The study was an observational analytic study with cross sectional design. A total of 60 patients with LBP. That data was collected with a questionairre and analyzed by using multiple logistic regression.

Results: Age $(\mathrm{OR}=2.09 ; 95 \% \mathrm{CI}=0.36$ to $12.09 ; \mathrm{p}=0.412)$, $\mathrm{sex}(\mathrm{OR}=1.52 ; 95 \% \mathrm{CI}=0.08$ to 28.78 ; $\mathrm{p}=0.781)$, high education $(\mathrm{OR}=2.38 ; 95 \% \mathrm{CI}=0.41$ to $14.05 ; \mathrm{p}=0.337)$, employment status $(\mathrm{OR}=$ 9.16; $95 \% \mathrm{CI}=1.35$ to $62.39 ; \mathrm{p}=0.024)$, proper body mechanics $(\mathrm{OR}=35.33 ; 95 \% \mathrm{CI}=1.65$ to 757.32; $\mathrm{p}=0.023)$, and perceptions of $\mathrm{LBP}(\mathrm{OR}=27.81 ; \mathrm{CI}=95 \% 2.14$ to $361.33 ; \mathrm{p}=0.011)$ increased LBP prevention. Poor environmental factors $(\mathrm{OR}=0.49 ; 95 \% \mathrm{CI}=0.02$ to $14.81 ; \mathrm{p}=0.684)$, poor environment accessibility $(\mathrm{OR}=0.73 ; 95 \% \mathrm{CI}=0.04$ to $14.22 ; \mathrm{p}=0.834)$, and weak family support $(\mathrm{OR}=0.30 ; 95 \% \mathrm{CI}=0.02$ to $5.50 ; \mathrm{p}=0.303)$ decreased LBP prevention.

Conclusion: Age, sex, high education, employment status, proper body mechanics, and perceptions of LBP increase LBP prevention. Poor environmental factors, poor environment accessibility, and weak family support decrease LBP prevention.
\end{abstract}

Keywords: personal factors, environmental factors, education on proper body mechanics, relapse prevention, LBP

Correspondence:

Rina Kurnia. Health Polytechnic, Ministry of Health Surakarta.

\section{BACKGROUND}

$\overline{\text { Every individual holds to perform activities }}$ or job to fulfill their needs. Some of the activities or jobs need quite big energy or muscle strength so that it may generate some ailments, one of them is Low Back Pain (LBP). LBP is the most commonly suffered skeletal muscle disorder among other skeletal muscle disorders (Depkes RI, 2007).

LBP is commonly found in daily practices, especially in Industrialized Countries. It is estimated that $70-85 \%$ citizens of developed countries have experienced the episode through their life (Sadeli, 2001). Five out of ten people experience recurrence every year (Tana dan Delima, 2013).

Factors related to the emergence of LBP ailment are among others personal factor that includes age in which the older the person is, the higher risk to catch LBP will be, sex types, body weight and body height, smoking habit, and environmental factor (occupational risk factor) in which both men and women do their activities excessively such as moving things, pushing, pulling, bending and working with continually twisting body. A lot of truck drivers 
Journal of Health Promotion and Behavior (2016), 1(1): 19-25

https://doi.org/10.26911/thejhpb.2016.01.01.03

suffer from Low Back Pain. Women who are frequently pregnant are also more at risk for LBP (Strong, 1996).

A study shows that $90,9 \%$ of LBP patients endure recurrence more than once in a year (Tana and Delima, 2013). Recurrence is common, usually it does not prevent patients from doing the activity, however what is concern is that if it turns to be chronic LBP with uncertain recurrence. The recurrence it self is triggered by patients' return to their activities after the pain episode ends. The activities are influenced by clinical, social and economic factor (Devo dan Weinstein, 2001).

Recurrence is caused by personal factors such as age, in which 41-64 is the most frequent age to suffer from recurrence, heavy physical worker is more frequent to suffer recurrence, male is likely to experience recurrence (Pogalad, 2010). Working environment factor may generate stress and it leads to recurrence (Novita, 2014), lack of family support may increase stressor so it leads to recurrence (Handayani, et al, 2012). In addition, lack of information is also related with recurrence (Sianturi, 2014).

Based on the data from Medical Rehabilitation Installation of RSUD Dr. Moewardi Surakarta (2015) there are 90 LBP patients in Medical Rehabilitation Installation of RSUD Dr. Moewardi Surakarta, in which $40 \%$ of them endure recurrence and $60 \%$ do not regularly visit Medical Rehabilitation Installation of RSUD Dr. Moewardi Surakarta so that the recurrence is not identified. Recurrence is caused by occupational risk factor and do not implement proper body mechanics education in their daily life. Medical Rehabilitation Installation of RSUD Dr. Moewardi Surakarta provide regular schedule for LBP patients to join therapy program with once a week visit arrangement.

\section{SUBJECTS AND METHOD}

The study was a qualitative study. The study approach used was observational analysis with Cross Sectional design. The population in the study was LBP patients in Medical Rehabilitation Installation of Dr. Moewardi hospital, Surakarta. A sample of 6o LPB patients was selected by purposive sampling.

The independent variable in the study were age, sex types, level of education, occupation, perception toward low back pain, access to healthcare service, environmental accessibility, family support, and proper body mechanic education, whereas the dependent variables in the study were Low Back Pain recurrence prevention.

Data collection technique used was primary data which were directly obtained from LBP patients who visited Medical Rehabilitation Installation of RSUD Dr. Moewardi Surakarta. The instrument of the study used was questionnaires which had been through Pearson product moment validity test and Alpha Cronbach reliability test.

\begin{tabular}{l}
\hline RESULTS \\
\hline Bivariate Analysis by using Chi Square \\
obtained the following result: there was an \\
association between age and LBP recur- \\
rence prevention and it was statistically sig- \\
nificant ( $\mathrm{p}=0.004$ ). There was an associa- \\
tion between female sex with LBP preven- \\
tion and it was statistically significant (OR= \\
3.44 ; $\mathrm{p}=0.031$ ). There was an association \\
between education level with LBP re- \\
currence prevention and statistically signi- \\
ficant ( $\mathrm{p}=0.046)$. There was an association \\
between occupation with LBP recurrence \\
prevention ( $\mathrm{p}=0.001$ ), there was an asso- \\
ciation between perception toward LBP \\
with LBP recurrence prevention and statis- \\
tically significant (OR=69.89; p=0.oo1), \\
there was an association between health-
\end{tabular}


care service access with LBP recurrence prevention and statistically significant $(\mathrm{OR}=9.0 ; \mathrm{p}=0.001$, there was an association between environmental accessibility with LBP recurrence prevention and statistically significant $(\mathrm{p}=0.001)$. There was an association between family support with

Tabel 1. The results of multiple logistic regression on the determinants of LBP prevention

\begin{tabular}{lcccc}
\hline \multirow{2}{*}{ Independent Variable } & \multirow{2}{*}{ OR } & \multicolumn{2}{c}{ 95\% CI } & \multirow{2}{*}{ p } \\
\cline { 3 - 4 } & & Lower Limit & Upper Limit & \\
\hline Age $\geq 65$ years & 2.09 & 0.36 & 12.09 & 0.412 \\
Female & 1.52 & 0.08 & 28.78 & 0.781 \\
Education & 2.38 & 0.41 & 14.05 & 0.337 \\
Employed & 9.16 & 1.35 & 62.39 & 0.024 \\
Perception toward LBP & 27.81 & 2.14 & 361.33 & 0.011 \\
Healthcare service access & 0.49 & 0.02 & 14.81 & 0.684 \\
Environmental accessibility & 0.73 & 0.04 & 14.12 & 0.684 \\
Family support & 0.30 & 0.02 & 5.50 & 0.419 \\
Proper body mechanics & 35.33 & 1.65 & 757.32 & 0.023 \\
N observation=60 & & & & \\
-2log likelihood= 22.77 & & & & \\
Nagelkerker R ${ }^{2}=82.0 \%$ & & & & \\
\hline
\end{tabular}

The result of multivariate analysis by using multiple logistic regression was used to find out the association of age, sex types, level of education, occupation, perception toward low back pain, access to healthcare service, environmental accessibility, family support, and proper body mechanic education with LBP recurrence prevention.

Table 1 showed that age $\geq 65$ years increased $\mathrm{LBP}$ prevention $(\mathrm{OR}=2.09$; 95\% $\mathrm{CI}=0.36$ to $12.09 ; \mathrm{p}=0.412)$, but it was statistically non-significant.

Table 1 showed that female sex increased LBP prevention $(\mathrm{OR}=1.52 ; 95 \%$ $\mathrm{CI}=0.08$ to $28.78 ; \mathrm{p}=0.781$ ), but it was statistically non-significant.

Table 1 showed that high education increased LBP prevention $(\mathrm{OR}=2.38$; 95\% $\mathrm{CI}=0.41$ to $14.05 ; \mathrm{p}=0.337$ ), but it was statistically non-significant.
LBP recurrence prevention and statistically tion between proper body mechanics education with LBP recurrence prevention and statistically significant $(\mathrm{OR}=22.67 ; \mathrm{p}=$ 0.001). significant $(\mathrm{p}=\mathrm{0.031})$, there was an associa-

Table 1 showed that employed patients increased LBP prevention $(\mathrm{OR}=9.16$; 95\% $\mathrm{CI}=1.35$ to $62.39 ; \mathrm{p}=0.024)$, and it was statistically significant.

Table 1 showed that employed patients increased LBP prevention (OR= 9.16; $95 \% \mathrm{CI}=1.35$ to $62.39 ; \mathrm{p}=0.024)$, and it was statistically significant.

Table 1 showed that positive perception toward LBP increased LBP prevention $(\mathrm{OR}=27.81 ; 95 \% \mathrm{CI}=2.14$ to $361.33 ; \mathrm{p}=$ o.011), and it was statistically significant.

Table 1 showed that difficult access to healthcare service decreased LBP prevention $(\mathrm{OR}=0.49 ; 95 \% \mathrm{CI}=0.02$ to $14.81 ; \mathrm{p}=$ o.684), but it was statistically non-significant.

Table 1 showed that poor environmental accessibility decreased LBP prevention $(\mathrm{OR}=0.73$; $95 \% \mathrm{CI}=0.04$ to $14.12 ; \mathrm{p}=$ 
Journal of Health Promotion and Behavior (2016), 1(1): 19-25

https://doi.org/10.26911/thejhpb.2016.01.01.03

o.684), but it was statistically non-significant.

Table 1 showed that weak family support decreased LBP prevention (OR= $0.30 ; 95 \% \mathrm{CI}=0.02$ to $5.50 ; \mathrm{p}=0.419$ ), but it was statistically non-significant.

Table 1 showed that proper body mechanics increased LBP prevention $(\mathrm{OR}=$ 35.33; $95 \% \mathrm{CI}=1.65$ to $757.32 ; \mathrm{p}=0.023$ ), and it was statistically significant.

The value of Negelkerke $\mathrm{R}^{2}$ is $82 \%$ it means that all the nine independent variables (age, sex, education, occupation, perception toward low back pain, access to healthcare service, environmental accessibility, family support, and proper body mechanic education are able to explain LBP recurrence prevention as much as $82.0 \%$ and the remain which is $18.0 \%$ is explained by other factors outside the study model.

\section{DISCUSSION}

The result of the study showed that the more the respondents approaching 65 year old and older, statistically ensured conducting Low Back Pain recurrence prevention, it is in accordance with the stdy result of Collins and O'Sullivan (2009) that was conducted to 200 women and 132 men in Ireland with age range between 18-66 years old. It obtained ailment on spine, shoulders and neck part were experienced more by younger respondents than the older ones.

Female respondents were more able to do low back pain recurrence prevention than male respondents. The result is supported by Michael (2001) that women have strong association in the emergence and women possess two times higher risk. Having the risk leads women to take care of their body more by doing LBP recurrence prevention.

The higher education is, the easier it takes to receive information on LBP and getting more able to do LBP recurrence prevention. This study is supported by Azizah et al. (2014), which states that the significant association between maternal education and the incidence of pneumonia on toddlers. the higher maternal education level is, the better prevention of pneumonia incidence and also vice versa.

Respondents who work full time will have higher risk for suffering from Low Back Pain so that they conduct the more Low Back Pain recurrence prevention. The study is supported by the study conducted by Umami et al. (2014) that most people who experience low back pain are those who have been working for $>10$ years and the most of them experience moderate pain ailment. Tenure is significantly associated with low back pain ailment ( $\mathrm{p}=0.001)$.

The higher one's perception toward low back pain is, the more low back pain recurrence prevention will be conducted in order not to suffer from severe illness. It is supported by a study conducted in Trelawny, Jamaika, by Bessler et al. (2015) which also states that $81 \%$ of the sample that cervical cancer is a very serious illness and conduct cervical cancer early detection. Meanwhile those who have low seriousness will not conduct cervical cancer early detection.

The easier access to healthcare service will improve the effort to conduct LBP recurrence prevention. The result of the study is supported by a study from Sari, et al. (2013) which states that travel distance to healthcare service is one of the important factor in utilizing healthcare service facilities. People are likely to utilize facilities which are close to their living place.

The more accessible the environment in respondents' surrounding is, the more capable to improve LBP recurrence preventive. The result of the study is supported by Pramayu (2013) who conveys that the ease of access to reach in the surrounding 
may affect toward one's convenience. If it is difficult to reach out things, it will gradually lead to discomfort and generate sore on the arms. Some ailments are symptoms to health problems since the effect of the factors, one of them is back pain.

The stronger support from the family to LBP patients through material, information, and emotional support will increase Low Back Pain recurrence prevention. The result of the study is supported by the study by Handayani et al. (2009) with its result that there is significant association between family support with the recurrence of moderate level of gastritis patients. The more frequent patients are exposed to proper body mechanics education then the more prevention efforts are conducted to reduce Low Back Pain recurrence. The result of the study is supported by a study from Nuranto (2010) that there is a significant difference in society's behavior between before and after the education about dengue fever prevention effort.

The result of multivariate analysis showed that the most dominant variable that is related to LBP recurrence prevention is perception toward $\operatorname{LBP}(p=0.011)$. It is in accordance with the Health Belief Model theory in which danger or pain that is suffered (perceived severity is related to the individual belief or faith about the severity or acuteness of the disease. Perception on the acuteness is often based on medical information or knowledge, also can be perceived from one's belief that he will get difficulties as the result of the disease and will generate to or affect on his life in general (Priyoto, 2014).

The study concluded that the most dominant variable in the prevention of LBP recurrence is the perception toward LBP variable which means the utilization of Health Belief Model theory is suitable to describe Low Back Pain recurrence prevention behavior.

\begin{tabular}{l}
\hline REFERENCE \\
\hline Azizah M, Fahrurazi, Qoriaty NI (2014). \\
Tingkat Pengetahuan dan Pendidikan \\
Ibu Balita dengan kejadian Penyakit \\
Pneumonia pada Balita di kelurahan \\
Keraton Kecamatan Martapura Kabu- \\
paten Banjar. An-Nadaa 1 (1). \\
Bessler P, Ncube B, Bey A, Knight J, Jolly \\
PE (2015). Factors associated with the \\
of cervical cancer screening among \\
women in Portland, Jamaica. NCBI. \\
7(3).
\end{tabular}

Collin MM, Bradley CP, O’Sulivan T, Perry IJ (2009). Self-care coping strategies in people with diabetes: A qualitative exploratory study. NCBI 9 (6).

Departemen Kesehatan RI, Direktorat Bina Kesehatan Kerja (2007). Seri pedoman tatalaksana penyakit akibat kerja bagi petugas kesehatan. penyakit otot rangka akibat kerja. Jakarta: Depkes RI.

Devo R, Weinstein JN (2001). Low Back Pain. England Journal Med 334: 363370.

Handayani SD, Kosasih CE, Priambodo AP (2012). Hubungan dukungan keluarga dengan kekambuhan pasien gastritis di Puskesmas Jatinangor. Bandung: Fakultas Ilmu Keperawatan Universitas Padjadjaran.

Meliala L, Pinzo R (2004). Patofisiologi dan Penatalaksanaan Nyeri Pinggang Bawah. Yogyakarta: Pain Symposium Towards Mechanism Based Treatment Michael R (2001). Physical, Psychosocial and Work Organization Factors on Injury/illness Absences. Diakses dari : http://www.ergoweb.com/news/detai l.cfm?id=340.

Murti B (2013). Desain dan ukuran sampel untuk penelitian kuantitatif dan kuali- 
Journal of Health Promotion and Behavior (2016), 1(1): 19-25

https://doi.org/10.26911/thejhpb.2016.01.01.03

tatif di bidang kesehatan. Yogyakarta:

Gadjah Mada University Press

Pogalad M (2008). Faktor yang berhubungan dengan kekambuhan penyakit reumatik di wilayah Puskesmas Anggrek Kaupaten Gorontalo Utara. Universitas Gorontalo.

Pramayu AR (2013). Office Ergonomic. Retrieved January 30, 2015, dari http:// www.premysisconsulting.com/2013/1 1/14/office-ergonomic/

Priyoto (2014). Teori Sikap dan Perilaku dalam Kesehatan. Yogyakarta: Nuha Medika.

Sadeli HA, Tjahyono B (2001). Nyeri punggung bawah. Dalam: Nyeri, Neuropatik, patofisiologi dan pelaksanaan. Jakarta: Perdossi.
Sari RM, Ambarita LP, Sitorus H (2013). Akses pelayanan kesehatan dan kejadian malaria di Provinsi Bengkulu. Media Litbangkes 23 (4).

Sianturi R (2014). Analisis faktor yang berhubungan dengan kekambuhan TB Paru. Unes Journal of Public Health 3(1).

Strong J (1996). Chronic pain the occupational therapist's perspective. Churchill Livingstone: Medical Division of Pearson Professional Limited.

Tana L, Delima (2013). Gambaran nyeri pinggang bawah pada paramedis di beberapa rumah sakit di Jakarta. Media Litbangkes. 23(1). 